University of Nebraska - Lincoln

DigitalCommons@University of Nebraska - Lincoln

Publications, Agencies and Staff of the U.S.

Department of Commerce

U.S. Department of Commerce

2011

Do Invasive Mussels Restrict Offshore Phosphorus Transport in

Lake Huron?

YoonKyung Cha

Duke University

Craig A. Stow

National Oceanic and Atmospheric Administration, craig.stow@noaa.gov

Thomas F. Nalepa

National Oceanic and Atmospheric Administration, thomas.nalepa@noaa.gov

Kenneth H. Reckhow

Duke University

Follow this and additional works at: https://digitalcommons.unl.edu/usdeptcommercepub

Part of the Environmental Sciences Commons

Cha, YoonKyung; Stow, Craig A.; Nalepa, Thomas F.; and Reckhow, Kenneth H., "Do Invasive Mussels Restrict Offshore Phosphorus Transport in Lake Huron?" (2011). Publications, Agencies and Staff of the U.S. Department of Commerce. 374.

https://digitalcommons.unl.edu/usdeptcommercepub/374

This Article is brought to you for free and open access by the U.S. Department of Commerce at DigitalCommons@University of Nebraska - Lincoln. It has been accepted for inclusion in Publications, Agencies and Staff of the U.S. Department of Commerce by an authorized administrator of DigitalCommons@University of Nebraska - Lincoln. 


\title{
Do Invasive Mussels Restrict Offshore Phosphorus Transport in Lake Huron?
}

\author{
YoonKyung Cha, ${ }^{\dagger}$ Craig A. Stow, ${ }^{*,+}$ Thomas F. Nalepa, $^{\dagger}$ and Kenneth H. Reckhow ${ }^{\dagger}$ \\ ${ }^{\dagger}$ Nicholas School of the Environment, Duke University, Durham, North Carolina 27708, United States \\ ${ }^{\ddagger}$ Great Lakes Environmental Research Laboratory, National Oceanic and Atmospheric Administration, 4840 South State Road, \\ Ann Arbor, Michigan 48108, United States \\ Supporting Information
}

ABSTRACT: Dreissenid mussels were first documented in the Laurentian Great Lakes in the late 1980s. Zebra mussels (Dreissena polymorpha) spread quickly into shallow, hard-substrate areas; quagga mussels (Dreissena rostriformis bugensis) spread more slowly and are currently colonizing deep, offshore areas. These mussels occur at high densities, filter large water volumes while feeding on suspended materials, and deposit particulate waste on the lake bottom. This filtering activity has been hypothesized to sequester tributary phosphorus in nearshore regions reducing offshore primary productivity. We used a

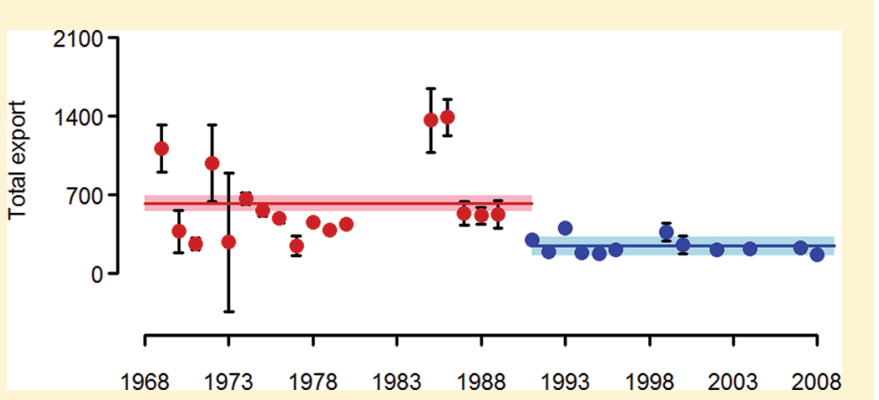
mass balance model to estimate the phosphorus sedimentation rate in Saginaw Bay, a shallow embayment of Lake Huron, before and after the mussel invasion. Our results indicate that the proportion of tributary phosphorus retained in Saginaw Bay increased from approximately 46-70\% when dreissenids appeared, reducing phosphorus export to the main body of Lake Huron. The combined effects of increased phosphorus retention and decreased phosphorus loading have caused an approximate $60 \%$ decrease in phosphorus export from Saginaw Bay to Lake Huron. Our results support the hypothesis that the ongoing decline of preyfish and secondary producers including diporeia (Diporeia spp.) in Lake Huron is a bottom-up phenomenon associated with decreased phosphorus availability in the offshore to support primary production.

\section{INTRODUCTION}

Though currently recognized as an important nutrient limiting primary productivity in freshwater ecosystems, ${ }^{1,2}$ phosphorus was scarcely mentioned in early work discussing eutrophication in the Laurentian Great Lakes. ${ }^{3}$ Subsequently, phosphorus was identified as the key limiting nutrient for primary producers in the Great Lakes and, amid considerable controversy, phosphorus reduction was identified as the management option necessary to control eutrophication. ${ }^{4}$ Consequently, the 1978 amendments to the Great Lakes Water Quality Agreement (GLWQA) between the United States and Canada ${ }^{5}$ established target phosphorus loads for the lakes, resulting in a phosphate detergent ban and enhanced sewage treatment. These efforts led to reductions in external phosphorus loading to the Great Lakes ${ }^{6}$ including Lake Huron. ${ }^{7}$

With diminished phosphorus levels, further nutrient management was a minor concern until the proliferation of invasive dreissenid mussels. ${ }^{8}$ Zebra mussels (Dreissena polymorpha) and quagga mussels (Dreissena rostriformis bugensis) modify biogeochemical processes and food web structure, altering phosphorus cycling and availability. ${ }^{9-12}$ Although some water quality characteristics, such as clarity, improved following the dreissenid invasion ${ }^{13-15}$ other eutrophication symptoms that had diminished with the implementation of phosphorus controls, including cyanobacterial blooms and nuisance benthic algal growth, have reappeared in nearshore areas. ${ }^{16-18}$ To explain this "re-eutrophication" despite lower phosphorus loads, the "nearshore phosphorus shunt" hypothesis contends that dreissenid mussel filtration and excretion have increased phosphorus retention and availability in nearshore areas; consequently, less phosphorus is transported offshore to support primary production and therefore less energy is available for the offshore food-web. ${ }^{19}$

Saginaw Bay is a large embayment $\left(\sim 2700 \mathrm{~km}^{2}\right)$ on the western side of Lake Huron (Figure 1). The bay is separated into an inner and outer region due to water circulation patterns and other physical features that make the two sections distinct. The inner bay (mean depth $\sim 5 \mathrm{~m}$ ) is warm, eutrophic, turbid, and experiences only intermittent vertical stratification. Input from the Saginaw River comprises approximately $70 \%$ of the flow into the bay and strongly influences the water quality characteristics of the inner bay. Approximately $70 \%$ of the inner bay bottom consists of sand, gravel, and cobble; the remainder is mud and silt. The outer bay (mean depth $\sim 14 \mathrm{~m}$ ) is colder,

Received: April 29, 2011

Accepted: August 3, 2011

Revised: August 2, 2011

Published: August 03, 2011 


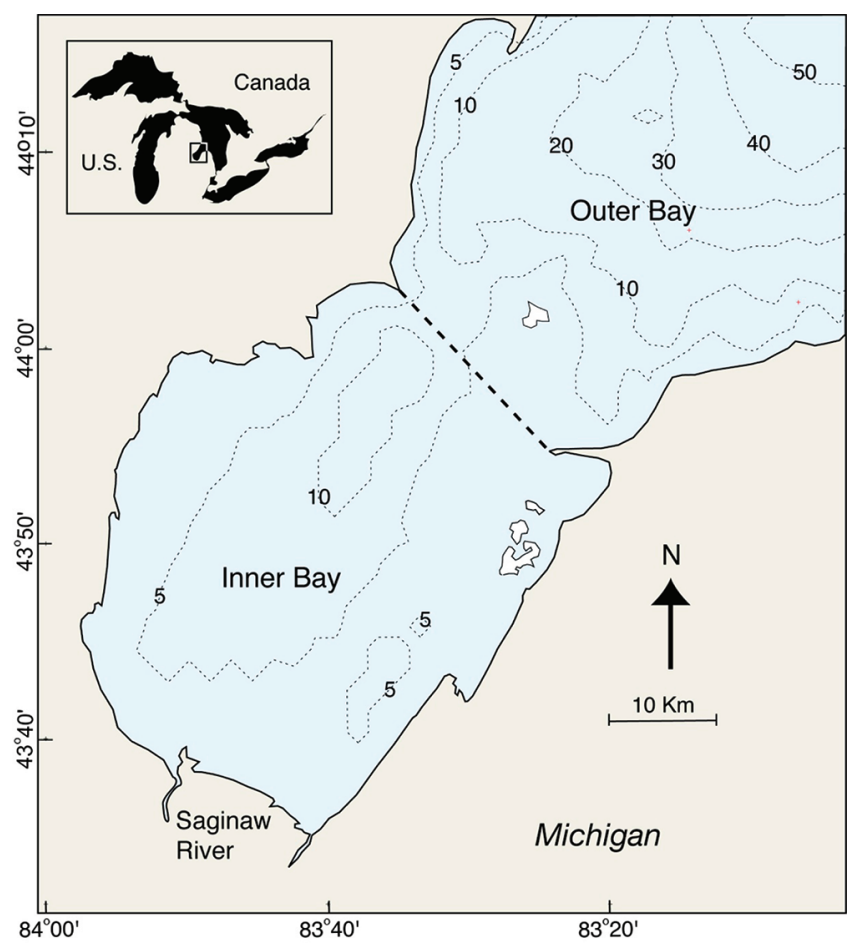

Figure 1. Map of the Canadian/United States Laurentian Great Lakes. Inset depicts Saginaw Bay, located on the southwestern side of Lake Huron. Contours depict depth $(\mathrm{m})$.

clearer and essentially an extension of the main body of Lake Huron which is generally nutrient-poor and oligotrophic. The eastern shore of the outer bay is rocky, the western shore sandy, most of the offshore consists of silty sand. ${ }^{20}$

In 1990 zebra mussels were discovered in the bay ${ }^{20}$ and by 1992 they were widespread and peaked with densities of $>30000$ $\mathrm{m}^{-2} \cdot{ }^{21}$ Following this peak, mean densities dropped and ranged from approximately $2000-5500 \mathrm{~m}^{-2}$ from 1993 to $1996 .^{21}$ Johengen et al. ${ }^{15}$ estimated that the mussel soft-tissue, standingstock of phosphorus ranged from 52 to 682 tonnes (1991-1993) indicating a high potential for phosphorus retention, though the long-term fate of phosphorus in mussel tissue, feces, or pseudofeces is unknown.

The nearly 20 year presence of mussels in Saginaw Bay provides an opportunity for a retrospective analysis to examine the long-term effect on mussel phosphorus sequestration and their influence on nearshore-to-offshore phosphorus transport. We use a mass balance model, with both historical and recently collected data, to estimate the annual phosphorus sedimentation (1968-2008) in Saginaw Bay, and the phosphorus export to Lake Huron, to examine if changes in these processes concurrent with the dreissenid invasion are discernible.

\section{MATERIALS AND METHODS}

We estimated annual phosphorus budgets using a mass balance model developed for Saginaw Bay. ${ }^{22,23}$ Net phosphorus sedimentation is determined by three components: external phosphorus inputs, changes in phosphorus storage and total phosphorus output as:

$$
\text { sedimentation }=\text { input } \pm \Delta \text { content }- \text { output }
$$

where total phosphorus output consists of advective and diffusive mass transport. In expanded form, net phosphorus sedimentation is calculated as

$$
S_{\mathrm{t}}=W_{\mathrm{pt}}-K \cdot\left\{V_{t} \cdot \Delta P_{t}+Q_{\text {out }_{t}} \cdot P_{t}+E_{\mathrm{t}}^{\prime} \cdot\left(P_{\mathrm{t}}-P_{\mathrm{out}_{t}}\right)\right\}
$$

where subscript $t$ denotes the year, $S$ is net phosphorus sedimentation rate (tonnes $\mathrm{yr}^{-1}$ ), $W_{\mathrm{p}}$ is external phosphorus input (tonnes $\left.\mathrm{yr}^{-1}\right), V$ is the volume of the inner bay $\left(\mathrm{m}^{3}\right), \Delta P$ is the difference in total phosphorus concentration of the inner bay from the previous year $\left(\mathrm{mg} \mathrm{L}^{-1} \mathrm{yr}^{-1}\right), Q_{\text {out }}$ is the hydrologic outflow from the inner bay $\left(\mathrm{m}^{3} \mathrm{yr}^{-1}\right), P$ is the total phosphorus concentration of the inner bay $\left(\mathrm{mg} \mathrm{L}^{-1}\right), E^{\prime}$ is bulk diffusion coefficient $\left(\mathrm{m}^{3} \mathrm{yr}^{-1}\right), P_{\text {out }}$ is the total phosphorus concentration of the outer bay, $K$ is a conversion factor $\left(10^{-6}\right), t$ is the index indicating annual mean values in year $t, 1968-2008$. Wp was calculated using a Bayesian hierarchical ratio estimation method. ${ }^{24}$ We incorporated unmonitored tributaries by increasing Saginaw River flow by $25 \%$ which approximates the ratio of the entire drainage area to the Saginaw River basin. ${ }^{7,25}$ We calculated $V$, by multiplying the inner bay surface area $\left(1,400 \mathrm{~km}^{2}\right)$ by the mean depth. Because annual water level fluctuations since the 1970s have been substantial relative to the depth of the bay we adjusted the mean depth used by Chapra ${ }^{22}$ with the annual water level information previously reported. ${ }^{26} \mathrm{We}$ estimated $Q_{\text {out }}$ based on annual mean inflow $\left(Q_{\text {in }}\right)$ and the annual difference in the amount of water contained in the inner bay:

$$
Q_{\text {out }}=Q_{\mathrm{in}_{t}}-\Delta \mathrm{V}_{t}+\mathrm{A}_{s} \cdot\left(\operatorname{Prec}_{t}-\mathrm{Evap}_{t}\right)
$$

where $\Delta V$ is the difference in $V$ from the previous year. $E^{\prime}$ was estimated using the chloride difference between the inner and outer bays and incorporating more recent information indicating chloride is not at steady-state. ${ }^{27} E^{\prime}$ was calculated as:

$$
E_{t}^{\prime}=\left\{W_{\mathrm{c}_{t}}-K \cdot\left(V_{t} \cdot \Delta \mathrm{Cl}_{t}+\mathrm{Q}_{\text {out }} \cdot \mathrm{Cl}_{t}\right)\right\} /\left(\mathrm{Cl}_{t}-\mathrm{Cl}_{\text {out }_{t}}\right)
$$

where $W_{\mathrm{c}}$ is annual mean external chloride input (tonne $\left.\mathrm{yr}^{-1}\right), \mathrm{Cl}$ and $\mathrm{Cl}_{\text {out }}$ are mean chloride concentrations of the inner and outer bay, respectively, $\left(\mathrm{mg} \mathrm{L}^{-1}\right)$, and $\Delta \mathrm{Cl}$ is the difference in chloride concentration of the inner bay from the previous year $\left(\mathrm{mg} \mathrm{L}^{-1} \mathrm{yr}^{-1}\right)$. Wc was estimated with the Bayesian hierarchical ratio estimation. ${ }^{24}$

We only estimated values in years for which both inner and outer bay total phosphorus data were available, thus we made no estimates from 1981 to 1984, 1990, 1997-1998, 2001, 2003, and 2005-2006 (Table 1). No inner bay chloride data were available from 1987 to 1989 and in these years we used the overall chloride mean from 1980 to 1990 . Outer bay chloride data were not available from 1986 to 1989 and 1999-2007 and in these years we used the overall mean from the entire time period. Outer bay chloride concentrations were consistently low $\left(<10 \mathrm{mg} \mathrm{L}^{-1}\right)$ and minimally variable.

To estimate the uncertainty of the annual net sedimentation values we generated 10000 Monte Carlo estimates for each year by drawing samples from independent distributions representing the mean annual total phosphorus concentrations and the annual total phosphorus inputs. This estimated uncertainty largely reflects the sample size in each year; some years were monitored intensively and others sparsely (Table 1). Chloride input estimates within years were minimally variable and were not included in the uncertainty estimates.

Phosphorus and chloride concentration data (Table 1) were obtained from the United States Environmental Protection Agency's online STORET database (1969-2005), the Michigan 
Table 1. Sources and Samples Sizes of Saginaw Bay Total Phosphorus and Chloride Data. Data Sources Were Numbered by 1 = Legacy STORET, 2 = Modern STORET, 3 = MDNRE, 4 = NOAA GLERL, and 5 = Bierman et al. ${ }^{7}$

\begin{tabular}{|c|c|c|c|c|c|}
\hline \multirow[t]{3}{*}{ year } & \multicolumn{4}{|c|}{ sample size } & \multirow[t]{3}{*}{ data source } \\
\hline & \multicolumn{2}{|c|}{ inner bay } & \multicolumn{2}{|c|}{ outer bay } & \\
\hline & $\mathrm{TP}$ & $\mathrm{Cl}$ & $\mathrm{TP}$ & $\mathrm{Cl}$ & \\
\hline 1969 & 3 & 3 & 1 & 1 & 1 \\
\hline 1970 & 2 & 2 & 1 & 1 & 1 \\
\hline 1971 & 10 & 6 & 12 & 6 & 1 \\
\hline 1972 & 5 & 5 & 6 & 6 & 1 \\
\hline 1973 & 2 & 2 & 1 & 1 & 1 \\
\hline 1974 & 91 & 10 & 30 & 9 & 1,5 \\
\hline 1975 & 119 & 23 & 31 & 1 & 1,5 \\
\hline 1976 & 117 & 18 & 26 & 4 & 1,5 \\
\hline 1977 & 5 & 5 & 4 & 4 & 1 \\
\hline 1978 & 76 & 5 & 16 & 4 & 1,5 \\
\hline 1979 & 90 & 4 & 16 & 2 & 1,5 \\
\hline 1980 & 120 & 9 & 24 & 5 & 1,5 \\
\hline 1981 & 0 & 0 & 2 & 1 & 1 \\
\hline 1982 & 0 & 0 & 0 & 0 & NA \\
\hline 1983 & 0 & 0 & 0 & 0 & NA \\
\hline 1984 & 0 & 0 & 0 & 0 & NA \\
\hline 1985 & 4 & 3 & 3 & 2 & 1 \\
\hline 1986 & 8 & 1 & 5 & 0 & 1 \\
\hline 1987 & 8 & 0 & 2 & 0 & 1 \\
\hline 1988 & 8 & 0 & 2 & 0 & 1 \\
\hline 1989 & 8 & 0 & 4 & 0 & 1 \\
\hline 1990 & 0 & 0 & 0 & 0 & NA \\
\hline 1991 & 141 & 143 & 21 & 17 & 4 \\
\hline 1992 & 142 & 142 & 17 & 17 & 4 \\
\hline 1993 & 76 & 76 & 12 & 9 & 4 \\
\hline 1994 & 64 & 64 & 9 & 7 & 4 \\
\hline 1995 & 56 & 56 & 7 & 7 & 4 \\
\hline 1996 & 62 & 27 & 7 & 7 & 4 \\
\hline 1997 & 16 & 16 & 0 & 0 & 1 \\
\hline 1998 & 19 & 19 & 0 & 0 & 1 \\
\hline 1999 & 20 & 20 & 4 & 0 & 2 \\
\hline 2000 & 16 & 16 & 4 & 0 & 2 \\
\hline 2001 & 39 & 39 & 0 & 0 & 2 \\
\hline 2002 & 53 & 53 & 2 & 0 & 2 \\
\hline 2003 & 45 & 45 & 0 & 0 & 2 \\
\hline 2004 & 54 & 54 & 1 & 0 & 2 \\
\hline 2005 & 38 & 38 & 0 & 0 & 2 \\
\hline 2006 & 56 & 56 & 0 & 0 & 3 \\
\hline 2007 & 42 & 42 & 2 & 0 & 3 \\
\hline 2008 & 17 & 20 & 3 & 3 & 4 \\
\hline
\end{tabular}

Department of Environmental Quality (2006-2007), previously reported ${ }^{7}$ information (1974-1980), and the National Oceanic and Atmospheric Administration Great Lakes Environmental Research Laboratory (NOAA GLERL) (1991-1996 and 2008-2009). Lake Huron annual average water level data were compiled by NOAA GLERL. The United States Geological Survey provided Saginaw River flow data.

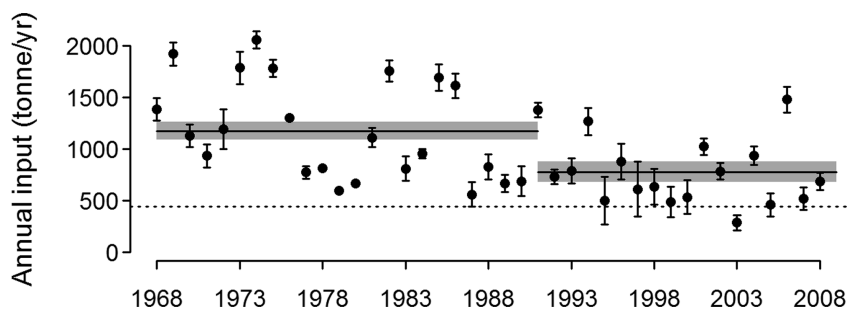

Figure 2. Estimated annual Saginaw Bay total phosphorus loads. Black dots depict mean estimate, error bars depict \pm one standard deviation of the predictive distribution. Black horizontal lines depict overall means for pre and post mussel periods; gray shading represents \pm one standard deviation of predictive distribution.

\section{RESULTS}

Annual total phosphorus load estimates reflect the effectiveness of point source controls ${ }^{28}$ implemented pursuant to the GLWQA as well as yearly tributary discharge variability (Figure 2). Due to inputs from point sources prior to regulation in the late 1970s, and several unusually wet years in the mid 1980s, the overall mean phosphorus load to Saginaw Bay was $1172( \pm 88)$ tonnes $\mathrm{yr}^{-1}$ before the dreissenid invasion ( \pm denotes one standard error). Since the invasion in the early $1990 \mathrm{~s}$, the overall mean load has been $775( \pm 100)$ tonnes $\mathrm{yr}^{-1}$. Only during unusually dry years have annual loads come close to meeting the 440 tonne $\mathrm{yr}^{-1}$ target established by the GLWQA.

Net phosphorus sedimentation differs yearly, but the overall mean was virtually unchanged after the dreissenid invasion, dropping slightly from $587( \pm 98)$ to $561( \pm 117)$ tonnes $\mathrm{yr}^{-1}$ (Figure 3a). However, because phosphorus loading has been lower in the postmussel era, the input phosphorus proportion retained in the sediments increased from $0.46( \pm 0.05)$ to 0.70 $( \pm 0.06)$ (Figure $3 \mathrm{~b})$. Consequently, total phosphorus export from the inner bay decreased from an overall mean of $624( \pm 69)$ tonnes $\mathrm{yr}^{-1}$ preinvasion to $247( \pm 82)$ tonnes $\mathrm{yr}^{-1}$ postinvasion (Figure 3c). As a proportion of phosphorus load the export dropped from $0.55( \pm 0.05)$ to $0.33( \pm 0.06)$ (Figure $3 \mathrm{~d}$ ). Our estimates indicate that export by turbulent diffusion exceeds advective export (Figures 3e and 3g, respectively) consistent with previously reported results. ${ }^{22}$ Diffusive export dropped from a mean of $430( \pm 70)$ to $154( \pm 83)$ tonnes $\mathrm{yr}^{-1}$ pre to postinvasion while advective export dropped from $194( \pm 15)$ to 93 $( \pm 15)$ tonnes $\mathrm{yr}^{-1}$. Relative to total phosphorus load these values represent pre to postinvasion drops from $0.38( \pm 0.05)$ to $0.22( \pm 0.06)$ and $0.17( \pm 0.01)$ to $0.11( \pm 0.01)$ for diffusive and advective export, respectively.

\section{DISCUSSION}

Retrospective analyses typically have caveats arising from influences that are confounded during the period of record as well as from the use of varying data sources with analytical protocols and sampling strategies that may have differed. In this analysis differentiating the mussel influence from the effects of decreasing loads is difficult; data in the transitional period during the implementation of phosphorus regulations and preceding the dreissenid invasion (1980-1990) are particularly unevenly distributed with a four year gap from 1981 to 1984 (Table 1). Additionally, proportional phosphorus sedimentation in the premussel period (1969-1990) was variable with high values occurring in the prephosphorus control period (before 1980) 
a)

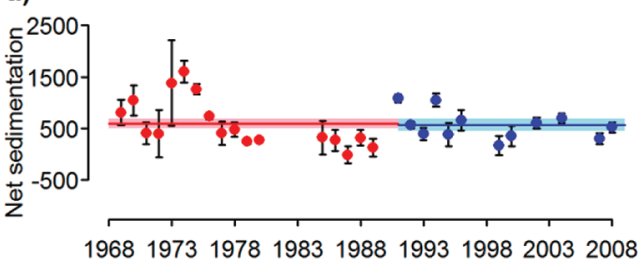

c)

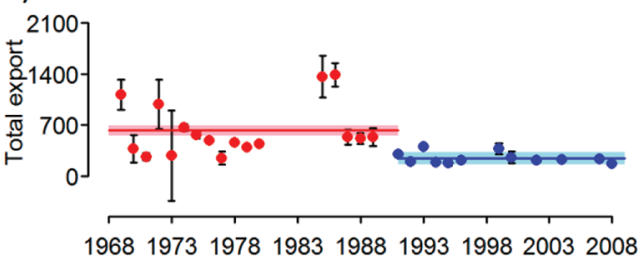

e)

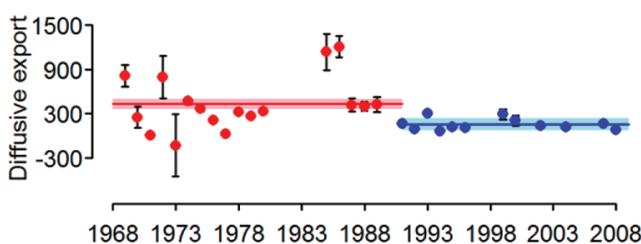

g)

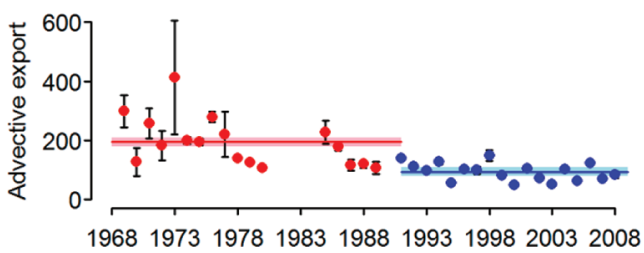

b)

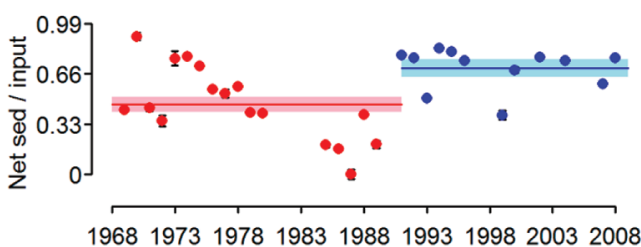

d)

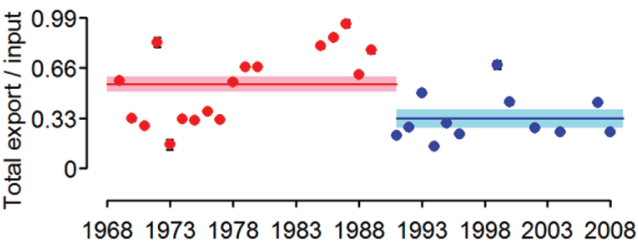

f)

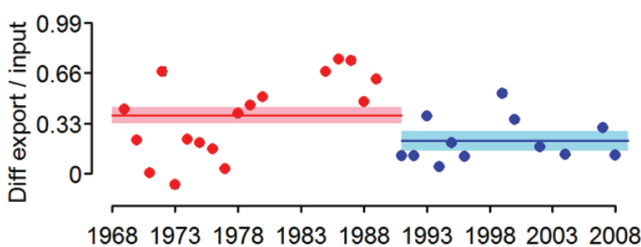

h)

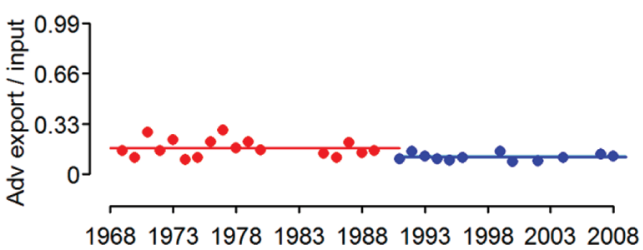

Figure 3. Annual estimates of net total phosphorus sedimentation (a), net total phosphorus sedimentation divided by total phosphorus load (b), total phosphorus export (c), total phosphorus export divided by total phosphorus load (d), diffusive total phosphorus export (e), diffusive total phosphorus export divided by total phosphorus load (f), advective total phosphorus export ( $\mathrm{g}$ ), and advective total phosphorus export divided by total phosphorus load (h). Error bars indicate \pm one standard error and reflect the uncertainties in the annual mean total phosphorus concentrations and the annual total phosphorus inputs. Horizontal lines represent overall means \pm one standard error pre (red) and post (blue) mussel invasion.

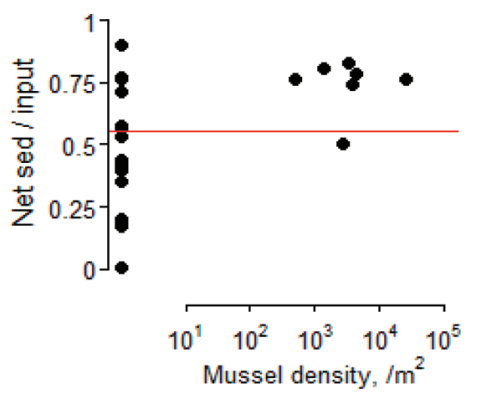

Figure 4. Annual mean net phosphorus sedimentation divided by annual total phosphorus load vs annual mean inner bay mussel density measured in NOAA GLERL diver surveys (1991-1996 and 2008). No mussels were present before 1990. Horizontal red line depicts overall average. Summary data is shown in Table 2.

that were similar to values since the mussel invasion, and low values in the midlate 1980s, after phosphorus control measures were implemented (Figure $3 \mathrm{~b}$ ). This pattern was likely due to the changing nature of the phosphorus inputs in response to control measures, and may reflect sediment phosphorus release
Table 2. Summary Data Used for Figure 4

\begin{tabular}{ccc} 
year & density $\left(\mathrm{no} . / \mathrm{m}^{2}\right)$ & biomass $\left(\mathrm{g} / \mathrm{m}^{2}\right)$ \\
1991 & $9308 \pm 6389$ & $12.3 \pm 7.6$ \\
1992 & $31334 \pm 15627$ & $58.6 \pm 28.1$ \\
1993 & $3803 \pm 1592$ & $4.5 \pm 2.1$ \\
1994 & $5633 \pm 1945$ & $9.2 \pm 2.4$ \\
1995 & $2562 \pm 1126$ & $4.9 \pm 1.6$ \\
1996 & $5261 \pm 3242$ & $14.7 \pm 6.4$ \\
2008 & $538 \pm 103$ & $2.0 \pm 0.4$ \\
\hline
\end{tabular}

as external inputs declined, but the available data do not support a definitive interpretation of the processes that caused the observed changes.

Nevertheless, in most years for which mussel density data are available the proportional phosphorus sedimentation during the mussel era has been minimally variable and above the average proportional sedimentation, suggesting that the mussels have stabilized the phosphorus retention efficiency at a relatively high level (Figure 4). In the postinvasion years there is no apparent relationship between mussel density and phosphorus proportion 
retained. The lack of relationship is not too surprising; based on filtration rates reported by Fanslow et al., ${ }^{29}$ even at the lower densities observed in 2008 the mussels would have the capacity to filter the entire volume of the inner bay $>10$ times during the reported hydraulic residence time of 120 days. ${ }^{15}$

Our results indicate that the combined effects of decreased phosphorus loads and a proportional increase in nearshore phosphorus retention are associated with an approximate $60 \%$ decrease in phosphorus export from the inner to the outer portion of Saginaw Bay. This estimated decrease is significant; Saginaw Bay is estimated to supply approximately $22-40 \%$ of the Lake Huron total phosphorus load, averaging approximately $28 \%$. $^{30}$ Concurrently, offshore phosphorus concentrations in Lake Huron have decreased and become comparable to those of oligotrohic Lake Superior. ${ }^{31}$

Since the mussel invasion, Lake Huron has suffered a collapse of the demersal fish community. ${ }^{32,33}$ More recently, key components of the zooplankton and benthic invertebrate communities have experienced a similar demise. ${ }^{34,35}$ Bottom-up nutrient limitation has been implicated as the likely cause of these food-web changes. ${ }^{36}$ Our results support the hypothesis that decreased offshore phosphorus transport is contributing to ongoing food web shifts. Dreissenid mussels enhance phosphorus retention in nearshore areas through the accumulation of particulate biodeposits in the sediments (feces and pseudofeces), and the excretion of bioavailable phosphorus that is sequestered by benthic primary producers that have benefited from increased water clarity. ${ }^{37}$ The decline of these food web components in Lake Huron may be exacerbated by the proliferation of the quagga mussel in the offshore region, ${ }^{35}$ further reducing water column nutrient availability. While phosphorus retention in Saginaw Bay is associated with ongoing eutrophication symptoms including cyanobacterial blooms and decaying benthic algae on beaches, ${ }^{38}$ the offshore food web is experiencing nutrient starvation. Thus, increased nearshore phosphorus retention, facilitated by the dreissenid invasion has led to a growing dichotomy between nearshore and offshore regions and a dilemma for resource managers. Analogous changes are underway, in differing degrees, in Lakes Michigan, Erie, and Ontario as well. $^{39-41}$ Policy-makers must consider these regime shifts when evaluating target loads that were established prior to the dreissenid invasion, particularly as Canada and the United States renegotiate the terms of the Great Lakes Water Quality Agreement.

\section{ASSOCIATED CONTENT}

S Supporting Information. Plot of Saginaw Bay annual chloride load estimates \pm one standard deviation, generated using the Bayesian hierarchical approach and a table of yearly chloride sample sizes used to generate the chloride load estimates. This material is available free of charge via the Internet at http://pubs.acs.org.

\section{AUTHOR INFORMATION}

\section{Corresponding Author}

*Phone: 734-741-2268; fax:734-741-2055; e-mail: craig.stow@ noaa.gov.

\section{ACKNOWLEDGMENT}

Cathy Darnell provided graphical support. This research was sponsored by a grant from the National Oceanic and
Atmospheric Administration Center for Sponsored Coastal Ocean Research. GLERL contribution number 1593.

\section{REFERENCES}

(1) Schindler, D. W. Evolution of phosphorus limitation in lakes. Science 1977, 195 (4275), 260-262.

(2) Schindler, D. W.; Hecky, R. E.; Findlay, D. L.; Stainton, M. P.; Parker, B. R.; Paterson, M. J.; Beaty, K. G.; Lyng, M.; Kasian, S. E. M. Eutrophication of lakes cannot be controlled by reducing nitrogen input: Results of a 37-year whole-ecosystem experiment. Proc. Natl. Acad. Sci. U.S.A. 2008, 105 (32), 11254-11258.

(3) Beeton, A. M. Eutrophication of the St. Lawrence Great Lakes. Limnol. Oceanogr. 1965, 10, 240-254.

(4) Schindler, D. W.; Vallentyne,J. R., The Algal Bowl; The University of Alberta Press: Edmonton, Alberta, Canada. 2008.

(5) Revised Great Lakes Water Quality Agreement of 1978; International Joint Commission, United States and Canada, 1978.

(6) DePinto, J. V.; Young, T. C.; Mcilroy, L. M. Great Lakes waterquality improvement-The strategy of phosphorus discharge control is evaluated. Environ. Sci. Technol. 1986, 20 (8), 752-759.

(7) Bierman, V. J.; Dolan, D. M.; Kasprzyk, R.; Clark, J. L. Retrospective analysis of the response of Saginaw Bay, Lake Huron, to reductions in phosphorus loadings. Environ. Sci. Technol. 1984, 18, 23-31.

(8) Hebert, P. D. N.; Muncaster, B. W.; Mackie, G. L. Ecological and genetic-studies on Dreissena polymorpha (Pallas)_A new mollusk in the Great Lakes. Can. J. Fish. Aquat. Sci. 1989, 46 (9), 1587-1591.

(9) Vanderploeg, H. A.; Nalepa, T. F.; Jude, D. J.; Mills, E. L.; Holeck, K. T.; Liebig, J. R.; Grigorovich, I. A.; Ojaveer, H. Dispersal and emerging ecological impacts of Ponto caspian species in the Laurentian Great Lakes. Can. J. Fish. Aquat. Sci. 2002, 59 (7), 1209-1228.

(10) MacIsaac, H. J. Potential abiotic and biotic impacts of zebra mussels on the inland waters of North America. Am. Zool. 1996, 36, 287-299.

(11) Thayer, S. A.; Haas, R. C.; Hunter, R. D.; Kushler, R. H. Zebra mussel (Dreissena polymorpha) effects on sediment, other zoobenthos, and the diet and growth of adult yellow perch (Perca flavescens) in pond enclosures. Can. J. Fish. Aquat. Sci. 1997, 54 (8), 1903-1915.

(12) Strayer, D. L.; Caraco, N. F.; Cole, J. J.; Findlay, S.; Pace, M. L. Transformation of freshwater ecosystems by bivalves-A case study of zebra mussels in the Hudson River. Bioscience 1999, 49 (1), 19-27.

(13) Holland, R. E. Changes in planktonic diatoms and water transparency in Hatchery Bay, Bass Island Area, Western Lake Erie since the establishment of the zebra mussel. J. Great Lakes Res. 1993, 19 (3), 617-624.

(14) MacIsaac, H. J.; Johannsson, O. E.; Ye, J.; Sprules, W. G.; Leach, J. H.; McCorquodale, J. A.; Grigorovich, I. A. Filtering impacts of an introduced bivalve (Dreissena polymorpha) in a shallow lake: Application of a hydrodynamic model. Ecosystems 1999, 2, 338-350.

(15) Johengen, T. H.; Nalepa, T. F.; Fahnenstiel, G. L.; Goudy, G. Nutrient changes in Saginaw Bay, Lake Huron, after the establishment of the zebra mussel (Dreissena polymorpha). J. Great Lakes Res. 1995, 21 (4), 449-464.

(16) Bykova, O.; Laursen, A.; Bostan, V.; Bautista, J.; McCarthy, L. Do zebra mussels (Dreissena polymorpha) alter lake water chemistry in a way that favours Microcystis growth? Sci. Total Environ. 2006, 371 (1-3), $362-372$.

(17) Vanderploeg, H. A.; Johengen, T. H.; Liebig, J. R. Feedback between zebra mussel selective feeding and algal composition affects mussel condition: did the regime changer pay a price for its success? Freshwater Biol. 2009, 54 (1), 47-63.

(18) Higgins, S. N.; Vander Zanden, M. J. What a difference a species makes: A meta-analysis of dreissenid mussel impacts on freshwater ecosystems. Ecol. Monogr. 2010, 80 (2), 179-196.

(19) Hecky, R. E.; Smith, R. E. H.; Barton, D. R.; Guildford, S. J.; Taylor, W. D.; Charlton, M. N.; Howell, T. The nearshore phosphorus shunt: A consequence of ecosystem engineering by dreissenids in the 
Laurentian Great Lakes. Can. J. Fish. Aquat. Sci. 2004, 61 (7), $1285-1293$.

(20) Nalepa, T. F.; Wojcik, J. A.; Fanslow, D. L.; Lang, G. A. Initial colonization of the zebra mussel (Dreissena polymorpha) in Saginaw Bay, Lake Huron: Population recruitment, density, and size structure. J. Great Lakes Res. 1995, 21 (4), 417-434.

(21) Nalepa, T. F.; Fanslow, D. L.; Lansing, M. B.; Lang, G. A. Trends in the benthic macroinvertebrate community of Saginaw Bay, Lake Huron, 1987 to 1996: Responses to phosphorus abatement and the zebra mussel, Dreissena polymorpha. J. Great Lakes Res. 2003, 29 (1), $14-33$.

(22) Chapra, S. C. Applying phosphorus loading models to embayments. Limnol. Oceanogr. 1979, 24 (1), 163-168.

(23) Chapra, S. C.; Reckhow, K. H., Engineering Approaches for Lake Management; Butterworth Publishers: Boston, 1983; Vol. 2.

(24) Cha, Y.; Stow, C. A.; Reckhow, K. H.; DeMarchi, C.; Johengen, T. H. Phosphorus load estimation in the Saginaw River, MI using a Bayesian hierarchical/multilevel model. Water Res. 2010, 44 (10), $3270-3282$.

(25) Canale, R. P.; Squire, J. A model for total phosphorus in Saginaw Bay. J. Great Lakes Res. 1976, 2 (2), 364-373.

(26) Sellinger, C. E.; Stow, C. A.; Lamon, E. C.; Qian, S. S. Recent water level declines in the Lake Michigan-Huron system. Environ. Sci. Technol. 2008, 42, 367-373.

(27) Chapra, S. C.; Dove, A.; Rockwell, D. C. Great Lakes chloride trends: Long-term mass balance and loading analysis. J. Great Lakes Res. 2009, 35 (2), 272-284.

(28) Chapra, S. C.; Robertson, A. Great Lakes eutrophicationEffect of point source control of total phosphorus. Science 1977, 196 (4297), 1448-1450.

(29) Fanslow, D. L.; Nalepa, T. F.; Lang, G. A. Filtration rates of the zebra mussel (Dreissena polymorpha) on natural seston from Saginaw Bay, Lake Huron. J Great Lakes Res 1995, 21 (4), 489-500.

(30) Schmitt Marquez, H.; Dolan, D. M.; Chapra, S. C. Interlake and total loading estimates of total phosphorus and chloride in the upper Great Lakes system, 1994-2008. J. Great Lakes Res. In review.

(31) Environment Canada and the United States Environmental Protection Agency. State of the Great Lakes 2009, 2009.

(32) Riley, S. C.; Roseman, E. F.; Nichols, S. J.; O’Brien, T. P.; Kiley, C. S.; Schaeffer, J. S. Deepwater demersal fish community collapse in Lake Huron. T. Am. Fish. Soc. 2008, 137 (6), 1879-1890.

(33) Riley, S. C.; Adams, J. V. Long-Term trends in habitat use of offshore demersal fishes in western Lake Huron suggest large-scale ecosystem change. T. Am. Fish. Soc. 2010, 139 (5), 1322-1334.

(34) Barbiero, R. P.; Balcer, M.; Rockwell, D. C.; Tuchman, M. L. Recent shifts in the crustacean zooplankton community of Lake Huron. Can. J. Fish. Aquat. Sci. 2009, 66 (5), 816-828.

(35) Nalepa, T. F.; Fanslow, D. L.; Pothoven, S. A.; Foley, A. J.; Lang, G. A. Long-term trends in benthic macroinvertebrate populations in lake Huron over the past four decades. J. Great Lakes Res. 2007, 33 (2), 421-436.

(36) Barbiero, R. P.; Lesht, B. M.; Warren, G. J. Evidence for bottomup control of recent shifts in the pelagic food web of Lake Huron. J. Great Lakes Res. 2011, 37 (1), 78-85.

(37) Ozersky, T.; Malkin, S. Y.; Barton, D. R.; Hecky, R. E. Dreissenid phosphorus excretion can sustain C. glomerata growth along a portion of Lake Ontario shoreline. J. Great Lakes Res. 2009, 35 (3), $321-328$.

(38) Higgins, S. N.; Malkin, S. Y.; Howell, E. T.; Guildford, S. J.; Campbell, L.; Hiriart-Baer, V.; Hecky, R. E. An ecological review of Cladophora glomerata (Chlorophyta) in the Laurentian Great Lakes. J. Phycol. 2008, 44 (4), 839-854.

(39) Barbiero, R. P.; Rockwell, D. C.; Warren, G. J.; Tuchman, M. L Changes in spring phytoplankton communities and nutrient dynamics in the eastern basin of Lake Erie since the invasion of Dreissena spp. Can. J. Fish Aquat. Sci 2006, 63 (7), 1549-1563.

(40) Watkins, J. M.; Dermott, R.; Lozano, S. J.; Mills, E. L.; Rudstam, L. G.; Scharold, J. V. Evidence for remote effects of dreissenid mussels on the amphipod Diporeia: Analysis of Lake Ontario benthic surveys, 1972-2003. J. Great Lakes Res. 2007, 33 (3), 642-657.

(41) Evans, M. A.; Fahnenstiel, G.; Scavia, D. Incidental oligotrophication of the North American Great Lakes. Environ. Sci. Technol. 2011, 45 (8), 3297-3302. 